\title{
The Use of Embryo Culture in Fruit Breeding
}

\author{
David W. Ramming \\ Horticultural Crops Research Laboratory, U.S. Department of Agriculture, Agricultural Research Service, \\ 2021 South Peach Avenue, Fresno, CA 93727
}

\section{Background}

The first successful systematic culture of plant embryos on an artificial medium of defined chemical composition was by E. Hanning in 1904 with mature embryos of two crucifers (Narayanaswami and Norstog, 1964). Then, in 1929, Laibach (Maheshwari, 1966) pointed out the potential application of embryo culture in plant breeding to rescue embryos from interspecific hybrids that otherwise fail due to embryo abortion. Tukey's (1933b) culture of cherry embryos in 1933 was a milestone in embryo culture of fruit crops. His medium and procedure has been widely used and even applied to other crops, such as cucurbits (Whitaker and Davis, 1962). Using this procedure, Blake (1939) was the first to employ culture in a peach breeding program.

LaRue (Narayanswami and Norstog, 1964) successfully cultured and grew small (0.5mm-long) embryos of many genera as early as 1936 with the addition of inorganic salts, sugar, yeast extract, and indolebutyric acid to the medium. However, embryos in the globular stage and smaller are very difficult to culture successfully. Maheshwari (1958) demonstrated by use of in ovule embryo culture that it is possible to grow a four-celled proembryo of Papaver somniferum L. to maturity. The successful growth of ovule-cultured embryos depends on their stage of maturity at the time of culture, genotype, culture medium, and culture environment.

The developing embryo is a dynamic system that has changing requirements as it ma-

Received for publication 8 Mar. 1989 The cost of publishing this paper was defrayed in part by the payment of page charges. Under postal regulations, this paper therefore must be hereby marked advertisement solely to indicate this fact. tures. The smaller the embryo, the more complex the medium required. Raghavan (1976) states in his review of embryo culture that there are heterotropic and autotropic stages in embryo development. The embryo in the heterotropic stage of development is smaller than in the autotrophic stage and usually requires the presence of growth regulators to allow for proper development. The autotropic stage begins at about the late heart stage and development of such an embryo does not depend on exogenous sources of growth regulators, thus making it more amenable to in vitro culture.

Embryo culture is useful when there is poor embryo development or abortion. Embryo abortion occurs in early ripening genotypes of Prunus where the flesh matures before seed maturity (Tukey, 1933a; Tukey and Lee, 1937), precluding their use as females in a breeding program. The poor germination of seeds from early ripening grapes is probably due to poor embryo development. Embryos have been rescued from early ripening Prunus (Tukey, 1934) and Vitis (Ramming and Emershad, 1984) cultivars, thus allowing their use as females. Many seedless grape cultivars are stenospermic (Stout, 1936), i.e., they are characterized by cessation of embryo development after fertilization and failure of seed development. Embryos have been rescued and grown into plants from stenospermocarpic seedless grapes (Emershad and Ramming, 1984; Spiegel-Roy et al., 1985), allowing growth of progeny resulting from the hybridization of seedless with seedless grapes. The production of interspecific hybrids is useful for the transfer of desirable genes from wild to cultivated species. In many cases, wide crosses between species are difficult to produce because of many factors that act as barriers. Postzygotic barriers such as endosperm abortion are a common occur- rence, but they have been overcome through the use of embryo rescue and many interspecific hybrids have been produced (Collins and Grosser, 1984). Embryo rescue has also been used to overcome postzygotic barriers during self- and cross-incompatibility (Fassuliotus, 1977; Cox et al., 1960; Fridriksson and Bolton, 1963).

Embryo culture has been used for rapid seed germination tests of peach (Tukey, 1944; Flemion, 1936) and other woody plants (Flemion, 1941, 1948); for production of virusfree citrus plants through culture of nucellar embryos (Bitters et al., 1970, 1972); and for studying the developmental and growth requirements of embryos (Steward and Hsu, 1977). Embryo culture has also been used to shorten breeding cycles in apple (Nickell, 1951) and iris (Randolph, 1945), where effective germination was reduced from years to months by overcoming dormancy. The possibility also exists for using embryo culture as a screening procedure. Landa et al. in 1980 (Collins and Grosser, 1984) investigated the possibility of selecting mutants with high amino acid content. Pollen might also be screened for temperature tolerance (Zamir and Vallejos, 1983) before in vitro fertilization of ovules. Embryo culture has been reviewed by Sanders and Ziebur (1963), Narayanaswami and Norstog (1964), Maheshwari (1966), Raghavan (1966, 1976, 1977, 1980), Bhojwani and Razdan (1983), and Collins and Grosser (1984). One of the few reviews of ovule culture was by Rangan (1984). This review will cover the use of embryo rescue for two fruit crops, Prunus and Vitis.

\section{Results achieved}

Peach embryo culture. After Tukey successfully cultured cherry embryos (1933 b), 
others applied it in their breeding programs. Blake (1939) used the procedure and Hough improve on the medium and procedure (Smith et al., 1969). Embryos with $75 \%$ fill $\left(\mathrm{PF}_{1}\right)$ could be rescued with this procedure. Peach embryo culture was started in 1975 at the Horticultural Crops Research Laboratory, Fresno, Calif., using Smith, Bailey, and Hough (SBH) medium (Smith et al., 1969) and procedures to develop progeny from early ripening genotypes and increase the chances of developing good early ripening cultivars. The technique of Smith et al. (1969) of cubing the fruit to remove all skin, surface-sterilizing with phenol, cracking the pit, surfacesterilizing the seed with merthiolate, and rinsing three times with distilled water was very time consuming and could be toxic to people. Since techniques and procedures used in breeding programs must be efficient, simple, and able to process many embryos, the above procedure was simplified. Our procedure, in Fresno, for embryo culture consisted of cracking the fruit and pit open to remove the seed and then flaming the seed in the laminar flow hood before extracting the embryo and placing it into the culture medium. Care must be taken to prevent damage during flaming. Damage occurs to the integument during flaming and the uptake of nutrients is reduced during ovule culture of very small embryos; hence, an alternative sterilization procedure for ovule culture was developed. The fruit is surface-sterilized with $70 \%$ ethanol for $30 \mathrm{sec}$, then with $0.525 \%$ $\mathrm{Na}$ hypochlorite for $5 \mathrm{~min}$ before it is cut open under sterile conditions and the seed is placed directly in the culture medium. Care must be exercised so the seed is not damaged or taken from open pits that generally are contaminated. Embryos from soft fruit have a greater chance of becoming contaminated

Table 1. Ripening dates of peach and nectarine cultivars used as parents and the earliest-maturing seedlings selected from their progeny.

\begin{tabular}{lccc}
\hline \hline & & \multicolumn{2}{c}{ Date ripe } \\
\cline { 3 - 4 } Parent & & $\begin{array}{c}\text { Parent } \\
\text { (1979) }\end{array}$ & $\begin{array}{c}\text { Earliest-ripening selected secdling } \\
\text { (May 1979) }\end{array}$ \\
\hline FV9-164 & Year cultured & 4 June & 5 \\
Springold & 1975 & 21 May & 10 \\
Springcrest & 1976 & 29 May & 10 \\
FV9-164 & 1976 & 4 June & 8 \\
Armking & 1976 & 7 June & 14 \\
Am Queen & 1976 & 10 June & 21 \\
\hline
\end{tabular}

${ }^{2}$ All open pollinated. because of free-flowing juice.

The first population; from six early ripening genotypes, having 70- to 72-day fruit development periods, were developed using SBH medium. Without embryo culture, plants could not be developed from these genotypes. The procedure allowed the selection of genotypes ripening 10 to 30 days earlier than the parents from these populations (Table 1). Embryo development in these very early ripening selections was less than in the parents; hence, the SBH medium was inadequate to support their growth. A more-defined medium was developed for the successful culture of these genotypes. Murashige and Skoog (MS) (1962) medium with the addition of $1240 \mathrm{mg}$ potassium succinate and $584.6 \mathrm{mg} \mathrm{L}$-glutamine per liter and 3\% sucrose allowed embryos as small as $5 \mathrm{~mm}$ long $\left(\mathrm{PF}_{1}=25\right)$ to be grown successfully. This was first used in the breeding program in 1980. All embryos longer than $10 \mathrm{~mm}$ are routinely cultured on SBH and those 5 to 10 $\mathrm{mm}$ long on MS. The recovery of viable plants from ovules and embryos has ranged from $41 \%$ to $79 \%$ since 1976 . Contamination is only a problem if inexperienced and untrained people perform the embryo culture. The successful use of embryo culture in our peach and nectarine breeding program from 1975 to 1987 is shown in Table 2. Embryos $<10 \mathrm{~mm}$ long are more difficult to grow successfully even though they are grown on a more complex medium (Table 3 ). Only $32 \%$ of such embryos produced plants, com-

Table 2. Number of ovules and embryos cultured, and percentage of seedlings that were planted in the greenhouse and field, contaminated, or had small embryos that did not grow, and number of seedlings selected and propagated in the peach and nectarine breeding program for $1975-87$.

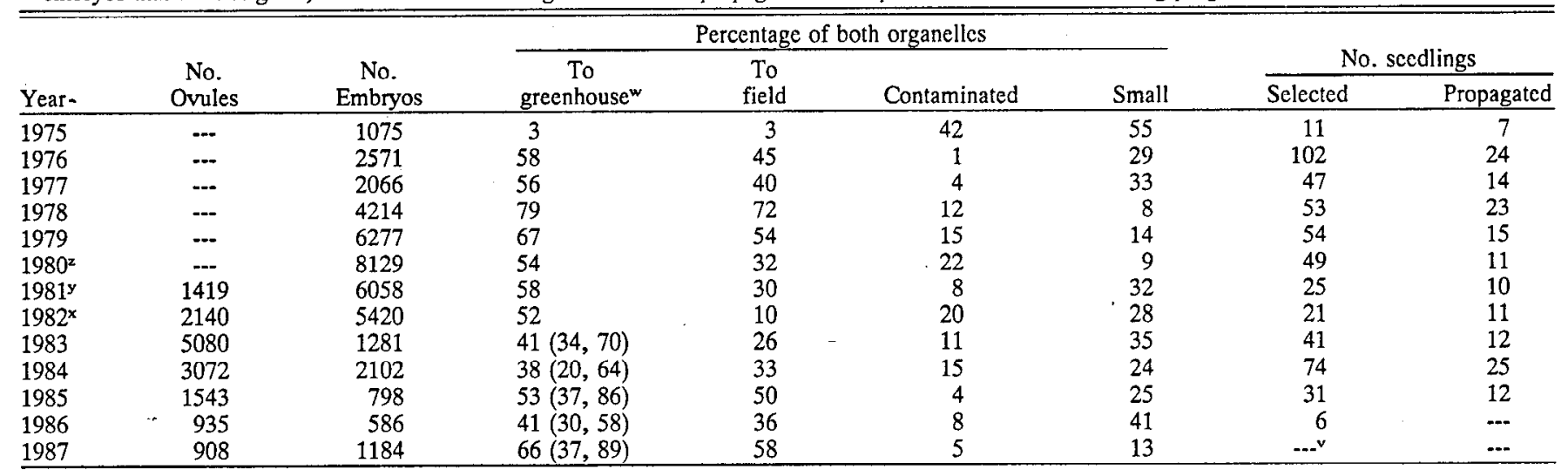

2MS and SBH media used and seed sterilized by flaming, starting year indicated.

yOvules cultured on cotton support in petri dish. Planted ovules as seed in greenhouse only in ycar indicated.

xOvules cultured on SH medium and sub-cultured in test tubes as embryos starting in year indicated.

wNumerals in parentheses: percentage of ovules and of embryos, respectively, planted in the greenhouse.

'Seedlings not fruiting.

Table 3. Number of peach ovules and embryos cultured on MS or SBH medium from 1983 to 1987 and the percent planted in the greenhouse.

\begin{tabular}{|c|c|c|c|c|c|c|c|c|c|c|}
\hline \multirow[b]{2}{*}{ Year } & \multicolumn{2}{|c|}{ - Ovule culture } & \multicolumn{4}{|c|}{ Embryo sub-cultured from ovule culture } & \multicolumn{4}{|c|}{ Embryo culture } \\
\hline & No. & $\begin{array}{c}\text { No. viable } \\
\text { embryos }\end{array}$ & $\begin{array}{l}\text { MS }^{2} \\
\text { (No.) }\end{array}$ & $\begin{array}{c}\text { Planted } \\
(\%)\end{array}$ & $\begin{array}{l}\mathrm{SBH}^{2} \\
\text { (No.) }\end{array}$ & $\begin{array}{c}\text { Planted } \\
\text { (No.) }\end{array}$ & $\begin{array}{c}\mathrm{MS}^{\mathbf{z}} \\
\text { (No.) }\end{array}$ & $\begin{array}{l}\text { Planted } \\
(\%)\end{array}$ & $\begin{array}{l}\mathrm{SBH}^{\mathrm{z}} \\
\text { (No.) }\end{array}$ & $\begin{array}{c}\text { Planted } \\
(\%)\end{array}$ \\
\hline$\overline{1983}$ & 5080 & 70 & 2325 & 35 & 1240 & 73 & 226 & 6 & 1055 & 84 \\
\hline 1984 & 3072 & 50 & 713 & 26 & 839 & 78 & 360 & 35 & 1753 & 86 \\
\hline 1985 & 1543 & 67 & 694 & 36 & 338 & 92 & 115 & 48 & 683 & 92 \\
\hline 1986 & 935 & 76 & 495 & 21 & 220 & 80 & 887 & 21 & 261 & 57 \\
\hline 1987 & 908 & 72 & 419 & 35 & 239 & 81 & 127 & 50 & 1057 & 93 \\
\hline
\end{tabular}

${ }^{2}$ Embryo length determined whether embryos were cultured on MS or SBH medium. Embryos $<10 \mathrm{~mm}$ long were cultured on MS and those $\geq 10 \mathrm{~mm}$ on SBH medium. 
pared to $78 \%$ for larger embryos.

Some recent selections ripen so early that their embryos are only $1 \mathrm{~mm}$ long at fruit maturity. The use of these selections as females required improvements in media and procedures. The cotton ovule culture medium of Stewart (1979) was tested for Prunus (Ramming, 1985), and it provided the necessary environment for the development of embryos initially 1.0 to $5.0 \mathrm{~mm}$ long. Cotyledons are well defined at this stage, and sucrose concentration was found to be more critical to embryo development and subsequent growth than cytokinins, auxins, or additional organic addenda. Sucrose at $6 \%$ to $8 \%$ during ovule culture was optimum for embryo fresh and dry weight accumulation and germination (Figs. 1 and 2). Precocious germination is prevented during ovule culture by the integuments, allowing the embryos to increase in fresh and dry weight within the integuments. At this time, the embryo is using the nucellus and endosperm as well as the nutrient medium for growth. Embryos were excised after 2 weeks of ovule culture and sub-cultured at various sucrose levels during stratification at $0.5 \mathrm{C}$. Embryo development continued during stratification,

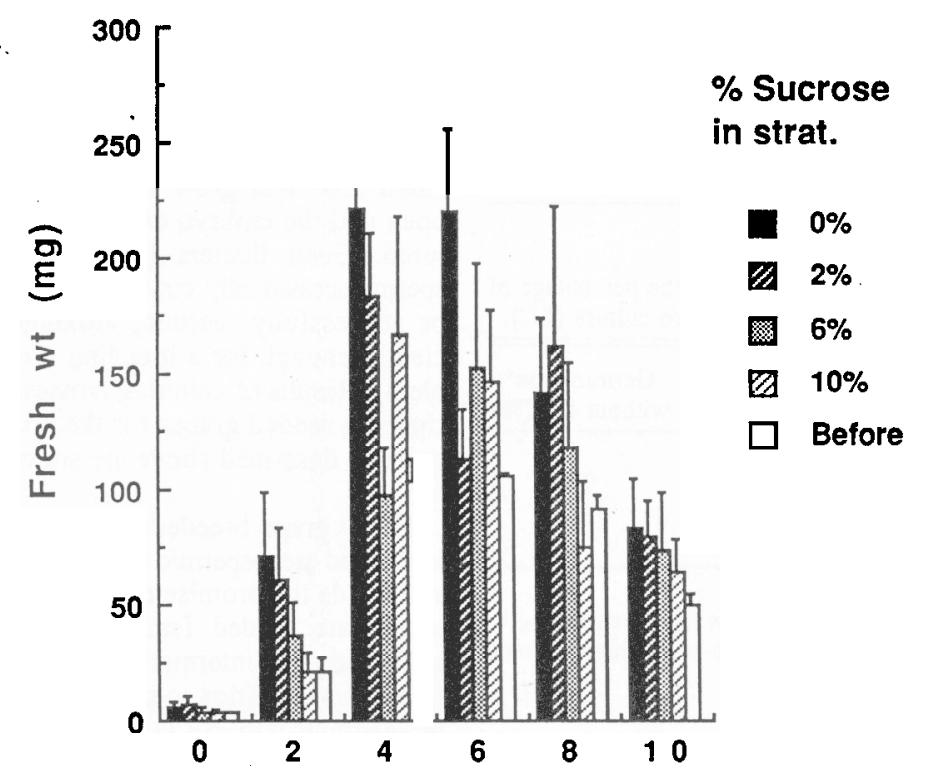

\section{a $\%$ Sucrose during initial culture}

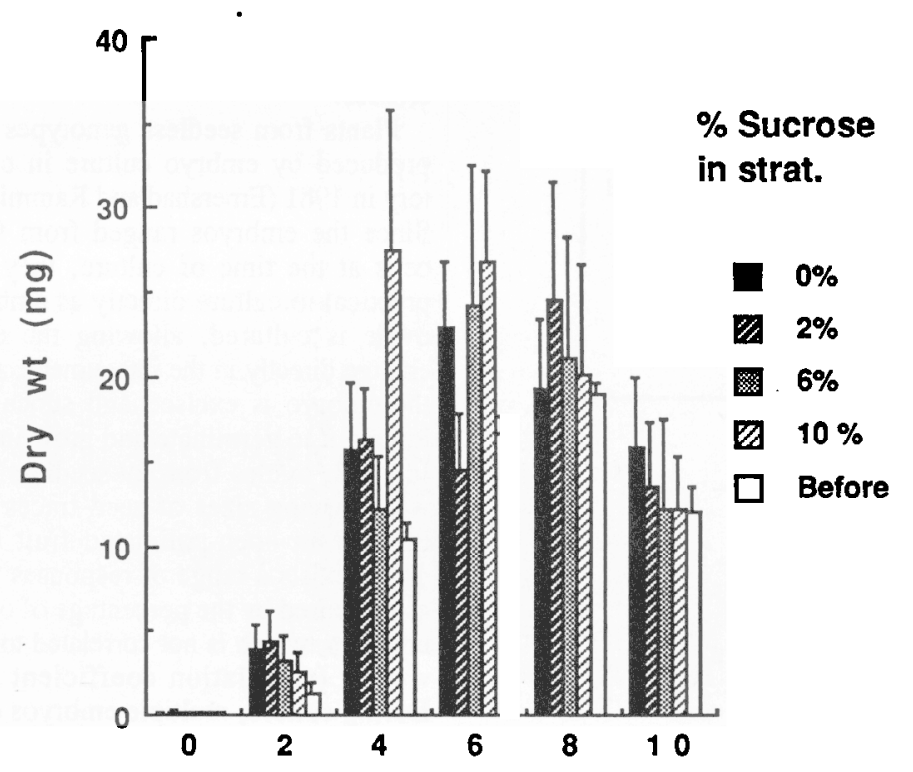

\section{b \% Sucrose during initial culture}

Fig. 1. Fresh weight (a) and dry weight (b) of 'Springold' peach embryos after 2 weeks of ovule culture and 45 days of stratification (strat.) at $0.5 \mathrm{C}$ at various sucrose levels. Embryo size was 2.1 $\mathrm{mm}$ at beginning of ovule culture. Vertical bars represent $95 \%$ confidence interval $(n=20)$.

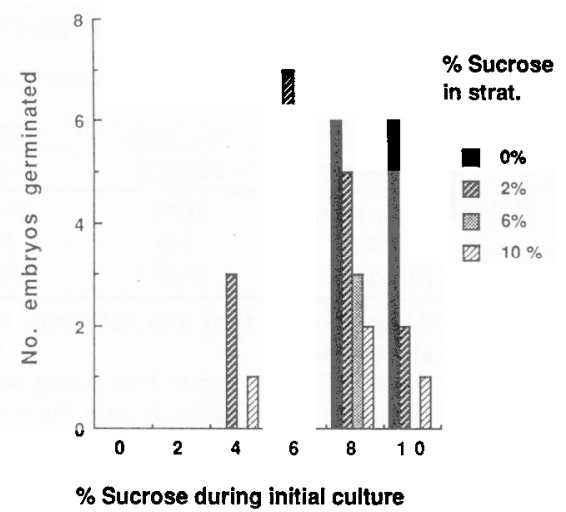

Fig. 2. The number of 'Springold' peach embryos that germinated after 2 weeks of ovule culture and 45 days stratification $(0.5 \mathrm{C})$ at various sucrose levels $(n=20)$.

increasing in fresh weight by $35 \%$ to $129 \%$ (Fig. 1). Lower sucrose levels (0\% and $2 \%)$ at this time were found to be the most beneficial for increase in fresh and dry weight and germination (Figs. 1 and 2). When ovule culture was first used in 1981, the embryos were not excised or subculture, but treated like mature seeds during stratification and germination. A higher percentage of plants developed when the embryos were excised after the initial 2 weeks of ovule culture and then subculture on either MS or SBH during the stratification period than when they were treated like mature seed. This superior procedure has been used since 1983 .

We have made many selections from seedlings produced by embryo culture methods. Two cultivars - Goldcrest peach and Mayfire nectarine-have resulted from embryo culture and are among the earliest of the commercially grown cultivars in California (Ramming and Tanner, 1987a, 1987b).

The culture of zygotes could be useful for rescuing embryos from interspecific hybrids that abort due to postzygotic barriers and for zygotic screening techniques. In 1986, we induced embryos 7 to 10 days post-bloom to enlarge to $\approx 12 \mathrm{~mm}$ (300 $\mathrm{mg}$ ). However, the embryos appeared to abort during stratification, and no viable plants were produced. Hormones during the initial ovule culture period were necessary as for tomato, and levels used were those described by Neal and Topoleski (1985). Additional work on Prunus is needed to be able to rescue zygotes.

Grape embryo culture. The seeds of many early ripening grapes do not germinate when they are stratified and planted in soil. These genotypes are valuable as females and as males to increase the chances of developing early ripening grape cultivars. Therefore, peach embryo culture techniques were applied to grapes. We used modified White's macroelements medium with Norstog's microelements and vitamins plus glycine and casein hydrolysate (Emershad and Ramming, 1984). Using this technique, we have improved initial germination from $0 \%-16 \%$ to $19 \%-24 \%$ and total plant production to $30 \%-32 \%$ (Table 4). Seeds are cultured individually in $20 \times 150$-mm test tubes, strat- 
Table 4. Number of seed and sub-cultured embryos that germinated from three early ripening seeded grape genotypes as a result of embryo culture.

\begin{tabular}{|c|c|c|c|c|c|c|c|c|}
\hline \multirow[b]{2}{*}{ Genotypes } & \multirow{2}{*}{$\begin{array}{l}\text { No. seed } \\
\text { cultured }\end{array}$} & \multicolumn{2}{|c|}{ Seed germinated } & \multirow{2}{*}{$\begin{array}{l}\text { No. embryos } \\
\text { germinated }^{\mathbf{z}}\end{array}$} & \multicolumn{2}{|c|}{ Plants } & \multirow{2}{*}{$\begin{array}{l}\text { No. plants } \\
\text { in field }\end{array}$} & \multirow{2}{*}{$\begin{array}{c}\text { Germination in } \\
\text { petri dish }{ }^{\mathbf{x}} \\
(\%)\end{array}$} \\
\hline & & No. & $\%$ & & Total & $\%$ & & \\
\hline Early muscat & 1079 & 204 & 18.9 & 142 & 346 & 32.1 & 190 & 0 \\
\hline C64-97 & 195 & 47 & 24.1 & 12 & 59 & 30.3 & 41 & 7 \\
\hline C66-151 & 1569 & 382 & 24.3 & 108 & 490 & 31.2 & 415 & 16 \\
\hline
\end{tabular}

2Ungerminated seed was cut open, embryo excised, and sub-cultured. Germination based on number of plants planted in the greenhouse.

yPlant difference due to loss during acclimation in the greenhouse.

xSimulated germination in soil. Only seeds containing endosperm (sinkers) were cultured.

Table 5. Number of early ripening grape seeds without endosperm (floaters) containing embryos and the number of plants obtained as a result of embryo culture.

\begin{tabular}{lcccc}
\hline \hline \multirow{2}{*}{ Genotype } & \multirow{2}{*}{$\begin{array}{c}\text { No. } \\
\text { floaters }\end{array}$} & No. & $\%$ & No. plants \\
\cline { 2 - 5 } & 221 & 56 & 25 & developed \\
\hline Early muscat & 139 & 17 & 12 & 7 \\
C64-97 & 424 & 141 & 33 & 0 \\
C66-151 & & & 11 \\
\hline
\end{tabular}

Table 6. Number of grape seed from early ripening genotypes embryo-cultured and the percentage of plants developed for the breeding program compared to germination without embryo culture (EC).

\begin{tabular}{|c|c|c|c|c|c|c|c|}
\hline \multirow[b]{2}{*}{ Year } & \multirow{2}{*}{$\begin{array}{l}\text { No. } \\
\text { crosses }\end{array}$} & \multirow{2}{*}{$\begin{array}{c}\text { No. } \\
\text { emasculations }\end{array}$} & \multicolumn{2}{|c|}{ Cultured seed } & \multicolumn{2}{|c|}{ Planted in field } & \multirow{2}{*}{$\begin{array}{c}\text { Germination }{ }^{\mathbf{x}} \\
\text { without EC (\%) }\end{array}$} \\
\hline & & & No. $^{2}$ & $\%$ & No. & $\%^{y}$ & \\
\hline $\begin{array}{l}1983 \\
1984 \\
1985 \\
1986\end{array}$ & $\begin{array}{r}8 \\
26 \\
40 \\
18\end{array}$ & $\begin{array}{l}32,740 \\
57,911 \\
69,813 \\
23,660\end{array}$ & $\begin{array}{l}3213 \\
3209 \\
4805 \\
3165\end{array}$ & $\begin{array}{r}9 \\
5 \\
7 \\
13\end{array}$ & $\begin{array}{r}656 \\
1219 \\
2192 \\
1282\end{array}$ & $\begin{array}{l}20 \\
37 \\
53 \\
40\end{array}$ & $\begin{array}{r}6 \\
27 \\
11 \\
5\end{array}$ \\
\hline
\end{tabular}

zOnly seeds containing endosperm (sinkers) were cultured.

The percentage germinated was higher, but plants were lost during acclimation in the greenhouse.

${ }^{x}$ Estimate of germination based on percentage germination in petri dishes and the percentage of each genotype making up seeds that were cultured.

\section{STANDARD METHOD}

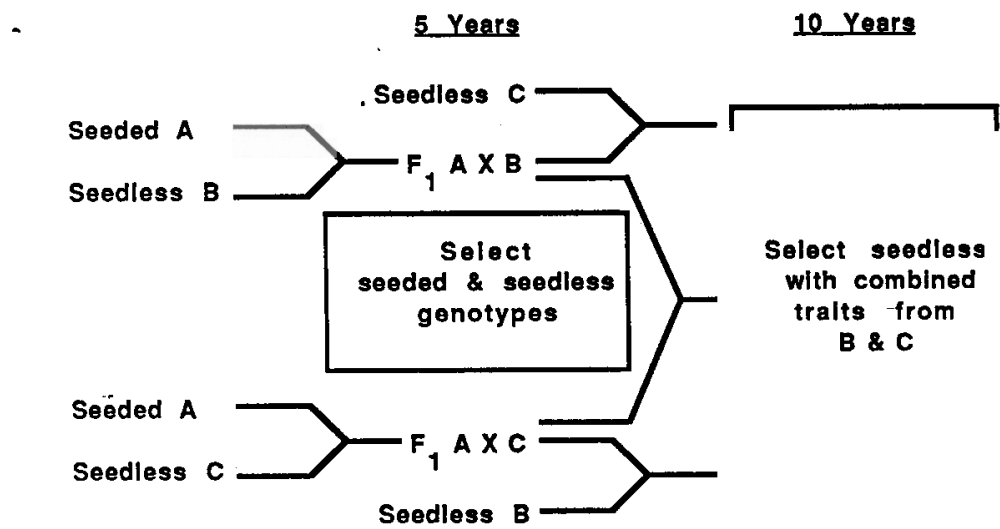

\section{EMBRYO CULTUREMETHOD}

5 Years

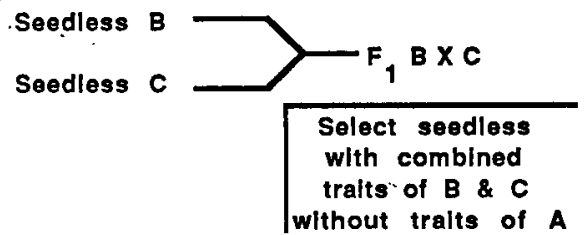

Fig. 3. Method for hybridization of seedless genotypes using a seeded female as the genetic bridge compared to direct hybridization of seedless made possible by embryo culture. ified for 3 months at $0.5 \mathrm{C}$, and then allowed to germinate. Some seed germinate immediately and are planted directly in the greenhouse. Some small embryos come out of the seed and germinate directly on the medium and can be planted in the greenhouse when large enough. Embryos from the ungerminated seed will grow when the seed is cut open and the embryo extracted and sub-cultured. Even floaters (seed without endosperm) occasionally contain embryos that can be successfully rescued, although not efficiently enough for a breeding program (Table 5). Results of culturing crosses from early ripening seeded grapes for the breeding program as described above are shown in Table 6.

Every grape breeder's dream has been to interbreed stenospermic seedless grapes. This step holds the promise of eliminating the intermediate seeded female and the second generation for intermating or back crossing (Fig. 3). In addition to saving one generation of seedlings and $\approx 5$ years; land, labor, fertilizer, and water are also saved. The genotypes can also be hybridized directly without being diluted by genes from a seeded female, making it easier to combine complementary traits. The proportion of seedless progeny should also be higher, requiring smaller populations to develop the same number of seedless seedlings as produced in seeded $\times$ seedless crosses.

Plants from seedless genotypes were first produced by embryo culture in our laboratory in 1981 (Emershad and Ramming, 1982). Since the embryos ranged from four to 50 cells at the time of culture, they were impractical to culture directly as embryos. The ovule is cultured, allowing the embryo to enlarge directly in the integument, after which the embryo is excised and subculture, allowing it to germinate and grow into a plant. In 1983, ovules from 29 seedless genotypes with varying sizes of seed traces were cultured from open-pollinated fruit (Table 7). There exists a range of responses to culture, as measured by the percentage of ovules with embryos, which is not correlated to seed trace weight (correlation coefficient $=0.19$ ) . During culture, multiple embryos develop in some ovules, usually as a result of somatic embryogenesis from the zygotic embryo. This conclusion was reached based on position of multiple embryos attached to zygote and on fruiting seedlings. The amount of multiple embryogenesis seems to be genotypic-dependent, based on data from culturing the 
Table 7. Number of ovules cultured, embryos developed, and size of embryos developed from seedless genotypes cultured in vitro in 1983.

\begin{tabular}{|c|c|c|c|c|c|c|}
\hline \multirow[b]{2}{*}{ Genotypes } & \multirow{2}{*}{$\begin{array}{c}\text { Seed trace } \\
\text { fresh wt }(\mathrm{mg})\end{array}$} & \multirow{2}{*}{$\begin{array}{l}\text { No. } \\
\text { ovules } \\
\text { cultured }\end{array}$} & \multicolumn{2}{|c|}{$\begin{array}{l}\text { Embryos } \\
\text { developed }\end{array}$} & \multirow{2}{*}{$\begin{array}{l}\text { Average embryo } \\
\text { size (mm) }\end{array}$} & \multirow{2}{*}{$\begin{array}{l}\text { No. } \\
\text { ovules with } \\
\text { multiple embryos }\end{array}$} \\
\hline & & & No. & $\%$ & & \\
\hline $\mathrm{C} 29-171$ & 42.3 & 53 & 22 & 42 & 1.5 & 0 \\
\hline B31-164 CSUF & 20.8 & 58 & 30 & 52 & 1.5 & 6 \\
\hline C $35-33$ & 17.6 & 60 & 24 & 40 & 1.9 & 0 \\
\hline C20-149 & 15.5 & 40 & 3 & 8 & 0.7 & 0 \\
\hline A74-61 & 15.2 & 64 & 16 & 25 & 1.3 & 8 \\
\hline B18-185 & 14.4 & 68 & 26 & 39 & 2.2 & 0 \\
\hline C85-82 & 11.7 & 64 & 37 & 58 & 2.1 & 7 \\
\hline A73-150 & 11.6 & 55 & 26 & 48 & 1.5 & 7 \\
\hline B46-112 Self & 11.2 & 74 & 51 & 69 & 9.5 & 1 \\
\hline $\mathrm{B} 1-68$ & 9.8 & 37 & 14 & 38 & 0.6 & 0 \\
\hline B29-82 & 9.7 & 30 & 10 & 34 & 2.3 & 0 \\
\hline B44-2 & 9.2 & 62 & 16 & 26 & 2.3 & 0 \\
\hline C58.22 & 8.8 & 74 & 10 & 14 & 4.5 & 0 \\
\hline C $88-89$ & 8.8 & 55 & 13 & 24 & 2.0 & 2 \\
\hline P60-58 & 7.8 & 61 & 31 & 51 & 3.5 & 1 \\
\hline B74-198 & 7.7 & 60 & 44 & 74 & 1.4 & 10 \\
\hline C76.79 & 7.1 & 68 & 9 & 14 & 0.8 & 1 \\
\hline Flame Seedless & 7.0 & 63 & 21 & 34 & 3.1 & 1 \\
\hline C18.36 & 6.8 & 52 & 1 & 2 & 0.1 & 0 \\
\hline C33-199 & 4.8 & 23 & 0 & 0 & $\ldots$ & -.. \\
\hline B5-15 & 4.7 & 60 & 23 & 39 & 1.4 & 0 \\
\hline $\mathrm{C} 22-121$ & 4.6 & 34 & 13 & 39 & 7.7 & 0 \\
\hline B73-167 & 4.4 & 61 & 24 & 40 & 2.7 & 4 \\
\hline $\mathrm{C} 89-173$ & 4.4 & 66 & 26 & 40 & 1.9 & 3 \\
\hline C84-116 & 4.3 & 46 & 13 & 29 & 0.8 & 0 \\
\hline Fiesta & 3.3 & 57 & 23 & 41 & 0.8 & 2 \\
\hline C67-7 & 1.7 & 67 & 33 & 50 & 1.9 & $\overline{1}$ \\
\hline A $8-2$ & 1.6 & 23 & 0 & 0 & -.. & $\ldots$ \\
\hline Thompson Seedless & 1.4 & 56 & 12 & 22 & 10.6 & 1 \\
\hline
\end{tabular}

Table 8. Number of aborted grape seeds cultured, and embryos and plants developed from seedless $x$ seedless crosses for the grape breeding program.

\begin{tabular}{|c|c|c|c|c|c|c|c|}
\hline \multirow[b]{2}{*}{ Year } & \multirow{2}{*}{$\begin{array}{c}\text { No. ovules } \\
\text { cultured }\end{array}$} & \multicolumn{2}{|c|}{$\begin{array}{l}\text { Embryos } \\
\text { developed }\end{array}$} & \multirow{2}{*}{$\begin{array}{l}\text { No, ovules with } \\
\text { multiple embryos }\end{array}$} & \multicolumn{2}{|c|}{$\begin{array}{l}\text { Plants }^{2} \text { set } \\
\text { in field }\end{array}$} & \multirow{2}{*}{$\begin{array}{l}\text { No. plants lost } \\
\text { during acclimation }\end{array}$} \\
\hline & & No. & $\%$ & & No. & $\%$ & \\
\hline 1983 & 4,075 & 647 & 21 & $\ldots y$ & 50 & 8 & -.. \\
\hline 1984 & 8,859 & 3203 & 36 & $\ldots y$ & 725 & 22 & 168 \\
\hline 1985 & 16,942 & 3781 & 22 & 596 & 1602 & 42 & 142 \\
\hline 1986 & 7,484 & 1124 & 15 & 160 & 341 & 30 & 69 \\
\hline 1987 & 10,670 & 2737 & 25 & 388 & 276 & 10 & $\cdots$ \\
\hline
\end{tabular}

${ }^{2}$ The percentage planted in the field is less than the actual number of plants developed due to plant loss during acclimation in the greenhouse.

YNumber of multiples not determined.

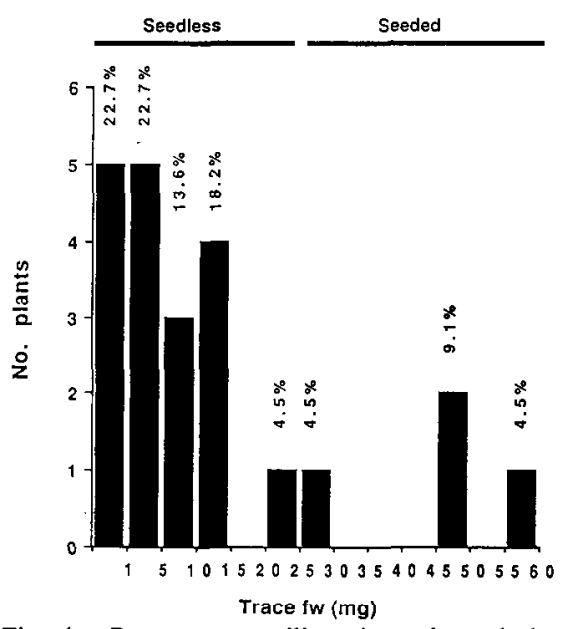

Fig. 4. Percentage seedlings in each seed size class from seedless $x$ seedless cross P79-101 $x$ C32-68. Based on average seed trace weight for 1986 and 1987 . Genotypes are generally classified as seedless if trace fresh weight is $<25$ mg. same genotypes for several years. Using ovule culture, many progeny have been developed from seedless $\times$ seedless grape crosses $(\mathrm{Ta}-$ ble 8). The first family that fruited has shown $82 \%$ seedlessness (Fig. 4) instead of the $15 \%$ average (Loomis and Weinberger, 1979) found in seeded $\times$ seedless progeny (Fig. 4). Genotypes with aborted seeds that are so small they are barely visible with the naked eye ( $<1 \mathrm{~mm}$ long) were found in $23 \%$ of the seedlings. One such seedling had larger berries than either parent, which is very encouraging in the development of naturally large fruit in seedless grapes.

Embryo culture can be a useful tool in breeding fruit crops and we have explored only a few of these. In addition to being able to culture embryos before abortion, it would be extremely valuable to be able to perform in vitro pollination and fertilization. Crossing barriers could be eliminated and the potential to screen male and female gametes before hybridization might be possible.

\section{Literature Cited}

Bhojwani, S.S. and M.K. Razdan. 1983. Plant tissue culture: Theory and practice. Elsevier, Amsterdam. p. 199-236.

Bitters, W.P., T. Murashige, T.S. Rangan, and E. Nauer. 1970. Investigations on established virus-free plants through tissue culture. Calif. Citrus Nurserymen's Soc. 9:27-30.

Bitters, W. P., T. Murashige, T.S. Rangan, and E. Nauer. 1972. Investigations on established virus-free plants through tissue culture, p. 267271. In: W.C. Price (ed.). Proc. 5th Conf. Intl. Organization Citrus Virologist. Gainesville, Fla. Blake, M.A. 1939. Some results of crosses of early ripening varieties of peaches. Proc. Amer. Soc. Hort. Sci. 37:232-241.

Collins, G.B. and J.W. Grosser. 1984. Culture of embryos, p. 241-257, In: I.K. Vasil (ed.). Cell culture and somatic cell genetics of plants. vol. 1. Laboratory procedures and their applications. Academic, Orlando, Fla

Cox, E.A., G. Stotzky, and R.D. Goors. 1960 In vitro culture of Musa balbisiana Colla embryos. Nature (London) 185:403-404.

Emershad, R.L. and D.W. Ramming. 1982. In- 
ovulo embryo culture of Vitis vinifera L. C.V. 'Thompson Seedless'. HortScience 17(4):576. (Abstr.)

Emershad, R.L. and D.W. Ramming. 1984. Inovu10 embryo culture of Vitis viniferaL. C.V. 'Thompson Seedless'. Amer. J. Bot. 71:873877.

Fassuliotus, G. 1977. Self fertilization of Cucumis metuliferus Naud. and its cross compatibility with Cucumis melo L. J. Amer. Soc. Hort. Sci. 102:336-339.

Flemion, F. 1936. A rapid method for determining the germinative power of peach seeds. Contrib. Boyce Thompson Inst. 8:289-293.

Flemion, F. 1941. Further studies on the rapid determination of the germinative capacity of peach seeds. Contrib. Boyce Thompson Inst. 11:455-464.

Flemion, F. 1948. Reliability of the excised embryo method as a rapid test for determining the germinative capacity of dormant seeds. Contrib. Boyce Thompson Inst. 15:229-242.

Fridriksson, S. and J.L. Bolton. 1963. Preliminary report on the culture of alfalfaembryos. Can. J. Bot. 41:439-440.

Loomis, N.H. and J.H. Weinberger. 1970. Inheritance studies of heedlessness in grapes. J. Amer. Soc. Hort. Sci. 104:181-184.

Maheshwari, N. 1958. In vitro culture of excised ovules of Papaver somniferum. Science 127:342.

Maheshwari, P. 1966. The embryology of angiosperms-A retrospect and prospect, p. 97112. In: E. Cutter (ed.). Trends in plant morphogenesis. Wiley, New York.

Murashige, T. and F. Skoog. 1962. A revised medium for rapid growth and bioassays with tobacco tissue cultures. Physiol Plant. 15:473497.

Narayanaswami, S. and K. Norstog. 1964. Plant embryo culture. Bot. Rev. 30:587-628.

Neal, C.A. and L.D. Topoleski. 1985. Hormonal regulation of growth and development of to- mato embryos in vitro. J. Amer. Soc. Hort. Sci. 110:869-873

Nickell, L.G. 1951. Embryo culture of weeping crabapple. Proc. Amer. Soc. Hort. Sci. 57:401405 .

Raghavan, V. 1966. Nutrition, growth and morphogenesis of plant embryos. Biol. Rev. 41:158.

Raghavan, V. 1976. Experimental embryogenesis in vascular plants: Academic, London.

Raghavan, V. 1977. Applied aspects of embryo culture, p. 375-397. In: J. Reinert and Y.P.S. Bajaj (eds.). Applied and fundamental aspects of plant cell, tissue, and organ culture. Springer-Verlag, New York.

Raghavan, V. 1980. Embryo culture. Intl. Rev. Cytol. Suppl. II. p. 209-240.

Ramming, D.W. 1985. In ovulo embryo culture of early-ripening Prunus. HortScience 20:419420.

Ramming, D.W. and R.L. Emershad. 1984. Embryo culture of early-ripening seeded grape genotypes. HortScience 19:594. (Abstr.)

Ramming, D.W. and O. Tanner. 1987a. 'Goldcrest' peach. Fruit Var. J. 41:52-53.

Ramming, D. W. and O. Tanner. 1987b. 'Mayfire' nectarine. Fruit Var. J. 41:80-81.

Randolph, L.F. 1945. Embryo culture of Iris seed. Bul. Amer. Iris Soc. 97:33-45.

Rangan, T.S. 1984. Culture of ovules, p. 227231. In: I.K. Vasil (ed.). Cell culture and somatic cell genetics of plants. vol. 1, Laboratory procedures and their applications. Academic Orlando, Fla.

Sanders, M.E. and N.K. Ziebur. 1963. Artificial culture of embryos, p. 297-326. In: P. Maheshwari (ed.). Recent advances in the embryology of angiosperms. Intl. Soc. Plant Morphologists, Delhi, India.

Smith, C.A., C.H. Bailey, and L.F. Hough. 1969. Methods for germinating seeds of some fruit species with special reference to growing seed- lings from immature embryos. New Jersey Agr. Expt. Sta. Bul 823.

Spiegel-Roy, P., N. Sahar, J. Baron, and U. Lavi. 1985. In vitro culture and plant formation from grape cultivars with abortive ovules and seeds. J. Amer. Soc. Hort. Sci. 110:109-112.

Stewart, J. McD. 1979. Use of ovule cultures to obtain interspecific hybrids of Gossypium, p. 45-56. In: J.T. Barber (ed.). Plant tissue culture-Proceedings of a symposium. Southern Section of Amer. Soc. of Plant Physiol. New Orleans, La.

Stewart, J. McD. and C.L. Hsu. 1977. In-ovulo embryo culture and seedling development of cotton (Gossypium hirsutum L.). Planta 137:113117.

Stout, A.B. 1936. Seedlessness. in grapes. New York Agr. Expt. Sta. Tech. Bul. 238.

Tukey, H.B. 1933a. Embryo abortion in earlyripening varieties of Prunus avium. Bot. Gaz. 94:433-468.

Tukey, H.B. 1933b. Artificial culture of sweet cherry embryos. J. Hered. 24:7-12.

Tukey, H.B. 1934. Artificial culture methods for isolated embryos of deciduous fruits. Proc. Amer. Soc. Hort. Sci. 32:313-322.

Tukey, H.B. 1944. The excised-embryo method of testing the terminability of fruit seed with particular reference to peach seed. Proc. Amer. Soc. Hort. Sci. 45:211-219.

Tukey, H.B. and F.A. Lee. 1937. Embryo abortion in the peach in relation to chemical composition and season of fruit ripening. Bot. Gaz. 98:586-597.

Whitaker. T.W. and G.N. Davis. 1962. Cucurbits botany; cultivation, and utilization. Leonard Hill, London.

Zamir, D. and E.C. Vallejos. 1983. Temperature effects on haploid selection of tomato microspore and pollen grains, p. 335-342. In: D.L. Mulcahy and E. Ottaviano (eds.). Pollen: Biology and implications for plant breeding, Elsevier, Amsterdam.

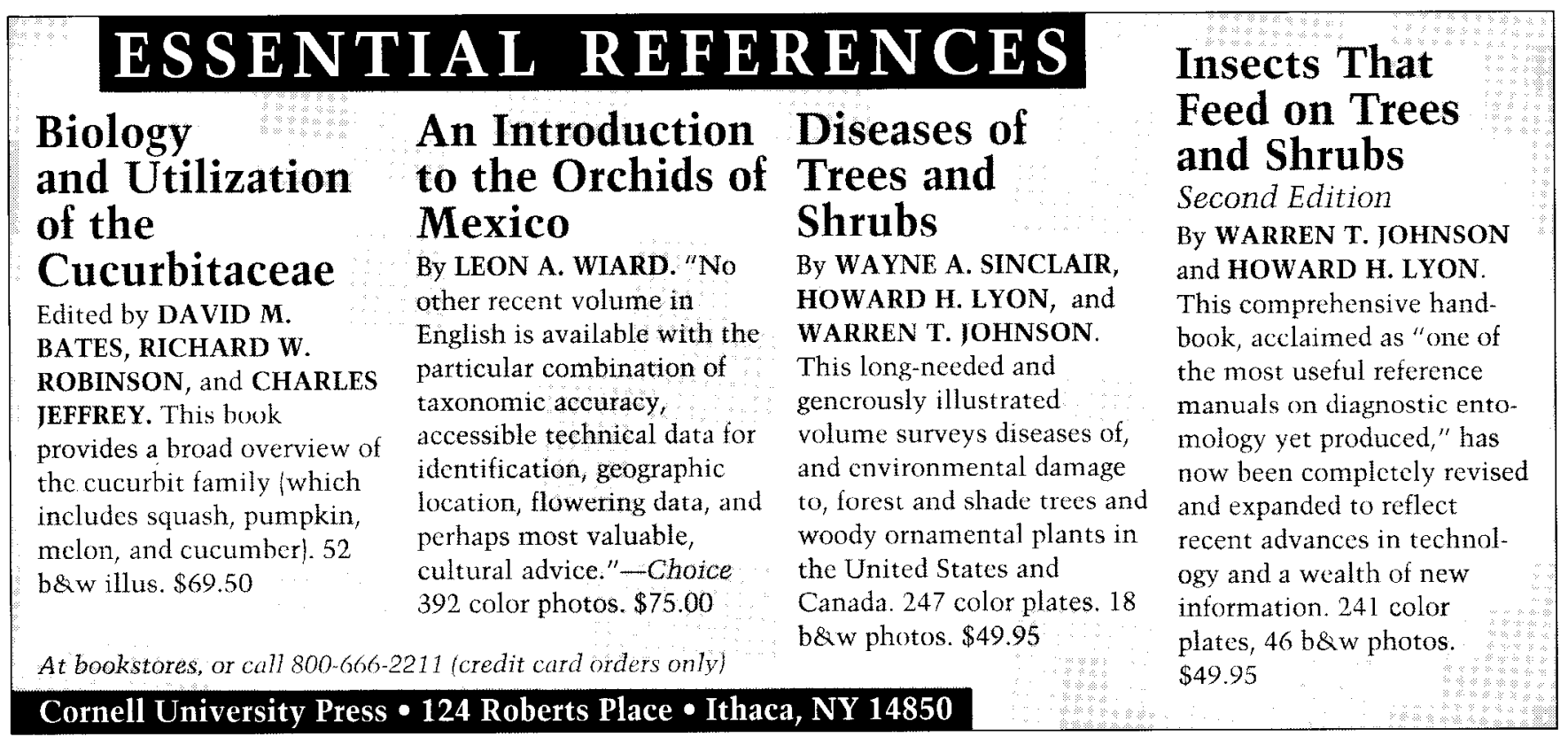

